\title{
Penerapan Strategi Marketting Mix dalam Upaya Meningkatkan Penjualan Keripik Pisang Makasy di Kota Sorong
}

\author{
Nahda Inayah ${ }^{1}$, Yusrial Syam ${ }^{2}$, Rais Dera Pua Rawi ${ }^{3}$, Evi Mufrihah Zein ${ }^{4}$, Bekti Wiji \\ Lestari $^{5}$, Retno Dewi Wijiastuti ${ }^{6}$ \\ 1, 2, 3, 4, 5, 6 Universitas Muhammadiyah Sorong, Sorong, Indonesia \\ *E-mail: nhdinayahh@gmail.com
}

\begin{abstract}
ABSTRAK
Pada umumnya masyarakat selalu menginginkan sesuatu yang berbeda, tidak terkecuali dengan hal kuliner atau makanan. Oleh karena itu dengan menciptakan Keripik Makasy ini konsumen bisa lebih tertarik, karena di kota sorong sendiri pengolahan pisang di buat seperti pisang nungget, pisang goreng keju, sudah sangat banyak. Jadi kami mengolah pisang menjadi sebuah keripik untuk menghadirkan varian baru dari makanan ringan sejenis.Olahan keripik pisang Makasy ini merupakan program kreativitas mahasiswa Universitas Muhammadiyah Sorong di Fakultas Ekonomi. Dan Keripik Pisang Makasy ini dibuat dengan tingkat higienis dan kebersihan yang tinggi serta tidak menggunakan bahanbahan kimia yang dapat merusak kesehatan seperti borax, formalin, pewarna buatan ataupun bahan berbahaya yang lain.Pada pengolahan Keripik Pisang Makasy ada beberapa bahan baku yang dibutuhkan seperti Pisang Mentah, kapur sirih,garam, air bersih. Dan keripik Makay memiliki berbagai varian rasa yaitu: balado, BBQ, jagung manis, jagung bakar, dan pedas manis.
\end{abstract}

Kata Kunci : Marketting Mix; Keripik Pisang Makasy; Kota Sorong

\section{Application of mix marketing strategies in an effort to increase the sale of makasy banana chips in the city of sorong}

\begin{abstract}
In general, people always want something different, including culinary or food. Therefore, by creating these Makasy Chips consumers can be more interested, because in the city of Sorong itself the processing of bananas is made like banana nungget, banana fried cheese, it has been very much. So we process bananas into chips to bring new variants of similar snacks. This processed Makasy banana chips is a creativity program of Sorong Muhammadiyah University students in the Faculty of Economics. And Makasy Banana Chips are made with high levels of hygiene and cleanliness and do not use chemicals that can damage health such as borax, formaldehyde, artificial coloring or other hazardous materials. In the processing of Makasy Banana Chips there are some raw materials needed such as Raw Banana, Betel Lime, Salt, Clean Water. And Makay chips have a variety of flavors: balado, BBQ, sweet corn, roasted corn, and sweet spicy.
\end{abstract}

Keywords: Marketting Mix; Makasy Banana Chips; City Of Sorong

\section{PENDAHULUAN}

Pisang (Musa Paradisiaca) merupakan salah satu komoditas buah unggulan Indonesia yamg memiliki kontribusi besar terhadap produksi buah - buahan nasional lainnya. Tanaman pisang di Indonesia dapat tumbuh subur di dataran rendah maupun dataran tinggi serta pada iklim basah maupun iklim kering. Buah pisang dapat ditemui dimana saja setiap saat karena 
tidak tergantung pada musim, sehingga tidak perlu menunggu lama untuk dapat memproduksi dan mengkonsumsi. Adanya peningkatan jumlah penduduk dan tingkat kesadaran masyarakat untuk mengkonsumsi buah-buahan, di harapkan dapat meningkatkan konsumi buah pisang secara nasional, sehingga kebutuhan buah pisang akan terus meningkat produksi pisang di Indonesia cenderung mengalami trend yang meningkat dengan jumlah produksi yang lebih besar dibandingkan dengan komoditi lain selama periode 2005-2009.

Buah pisang kaya akan manfaat dan mempunyai kandungan gizi sangat baik, antara lain menyediakan energy cukup tinggi dan mengandung protein yang kadarnya lebih tinggi dibandingkan dengan buah-buahan lain. Selain untuk konsumsi langsung, pisang juga dapat dijadikan berbagai olahan makanan yang enak.Buah pisang dapat diolah dalam keadaan mentah maupun masak.Pisang kaya mineral seperti protein, kalium, magnesium, fosfor, besi, dan kalsium.Pisang juga mengandung vitamin C, B kompleks, B6, dan serotonin yang aktif sebagai neurotransmitter dalamkelancaran fungsi otak.Pisang mentah dapat dioleh menjadi gaplek, tepung, dan keripik. Sedangkan pisang matang dapat diolah sari buah, pisang goreng, pisang rebus, selai, dodol,.Dari beberapa pisang olahan yang ada, pisang dewaka merupakan pisang yang produksinya sangat melimpah. Sangat mudah dijumpai dan jenis pisang yang paling baik dijadikan kripik pisang.

Peluang dalam bisnis keripik pisang makasy dinilai sebagai potensi untuk pendapatan sampingan mahasiswa dan sebagai potensi nilai usaha. Olahan pisang juga dapat membantu perekonomian pendapatan produksi pisang. Keripik pisang makasy pada awalnya dipasarkan dilingkungan kampus, karena banyaknya permintaan dan feedback yang positif dari konsumen sehingga membuat potensi bisnis sangat menjanjikan. Penelitian ini bertujuan untuk mengetahui penerapan strategi marketting mix dalam upaya meningkatkan kapasitas penjualan keripik pisang di Kota Sorong. Bisnis keripik pisang pada dasarnya memang sangat mudah di jalankan dengan modal yang tidak terlalu besar. Dengan begitu maka membuat laba yang diperoleh nantinya sangat menggiurkan. Bisnis keripik pisang kini banyak disukai kalangan masyarakat kota sorong maupun para wisatawan yang datang dikota sorongsebagai cemilan dan oleh oleh.

\section{METODE}

Penelitian ini bertempat di Jln.Sadewa II km.12 masuk yang merupakan tempat produksi keripik pisang Makasy.Waktu penelitian ini berlangsung selama 3-4 jam dalam sehari.Metode yang digunakan dalam penelitian ini ialah metode kualitatif dan deskriptif.Setelah metode kami tetapkan, berikutnya kami menentukan teknik pengumulan data yang sesuai dengan metode yang dipakai dalam peneltian.Kami melakukan wawancara secara langsung kepada pemilik sekaligus yang memproduksi keripik pisang Makasy.

\section{HASIL DAN PEMBAHASAN}

Kondisi Umum Lingkungan dalam kegiatan usaha keripik pisang ini bergerak di bidang penjualan makanan ringan atau bisa juga disebut cemilan.Keripik pisang merupakan suatu cemilan yang tidak sedikit orang menggemarinya, selain rasanya yang enak harganya juga terjangkau dan mudah ditemukan di daerah mana saja. Di Kota Sorong sendiri, masih kurang penjualan keripik pisang. Melihat peluang itu akhirnya terjadilah Keripik Pisang Makasy, bukan hanya menjadi cemilan di kota sorong tetapi Keripik Pisang Makasy sudah menjadi oleholeh.

Potensi Sumberdaya Alam, Pisang merupakan komoditas yang paling banyak dikonsumsi masyarakat indonesia, karena sekitar $45 \%$ konsumsi buah-buahan adalah pisang, pisang sering dimakan segar, dibikin kolak, dibakar dan dikukus atau dibuat tepung. Pisang dapat dimakan dalam berbagai cara, bisa dibuat kue, digoreng, dan direbus. Bukan hanya itu pisang juga dapat di olah menjadi sesuatu yang sangat unik, yaitu membuat pisang menjadi keripik.Kita sendiri tahu bahwa di Indonesia banyak sekali orang yang suka ngemil, oleh karena itu dengan adanya keripik Pisang Makasy orang bnyak tidak takut buat mengemil keripik pisang karena bahan yang kita gunakan semunya sehat dan tanpa pengawet. 
Membangun usaha Keripik Pisang Makasy sampai bisa mendapatkan keuntungan hingga terus berlanjut dan berkembang, yaitu dengan cara membuat Keripik Pisang Makasy ini dengan berbagai varian rasa yang baru agar disemua kalangan mulai anak-anak sampai orang dewasa akan menyukai cemilan Keripik Pisang Makasy. Melakukan promosi hal ini akan membuat Keripik Pisang Makasy bisa lebih cepat terjual dan juga di kenal oleh banyak masyarakat misal di kampus atau pusat perbelanjaan. Beberapa promosi bisa dapat dilakukan dengan cara memalalui social media, cara ini bisa di jalankan dan cukup efektif karena saat ini banyak yang memiliki media-media online seperi facebook.

Penerapan strategi marketing mix yaitu produk yang kami buat dengan tingkat higienis dan kebersihan yang tinggi serta tidak menggunkan bahan-bahan kimia yang dapat merusak kesehatan seperti borax, formalin, pewarna buatan ataupun bahan berbahaya lainnya. Adapun harga yang kami tawarkan yaitu kripik pisang rasa original, balado, jagung manis, BBQ dengan berat 50gr seharga Rp 5.000, berat 100gr seharga Rp 10.000, berat 150gr seharga Rp 15.000.

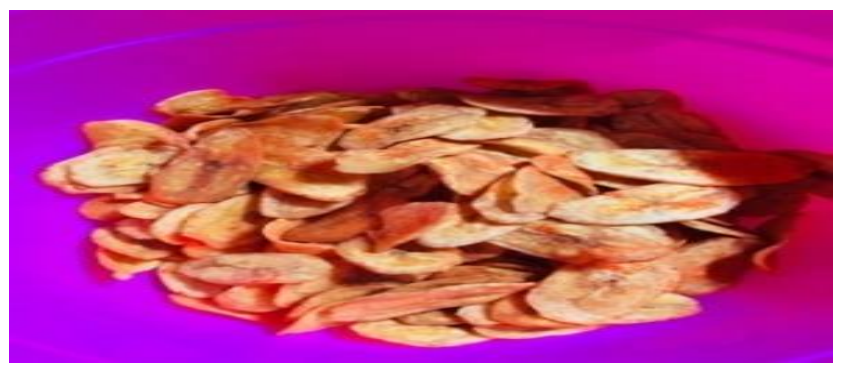

Gambar 1. Hasil Keripik Pisang yang Telah Diberikan Bumbu

Pada gambar 7 menjelaskan bahwa hasil keripik pisang yang telah diberikan bumbu.

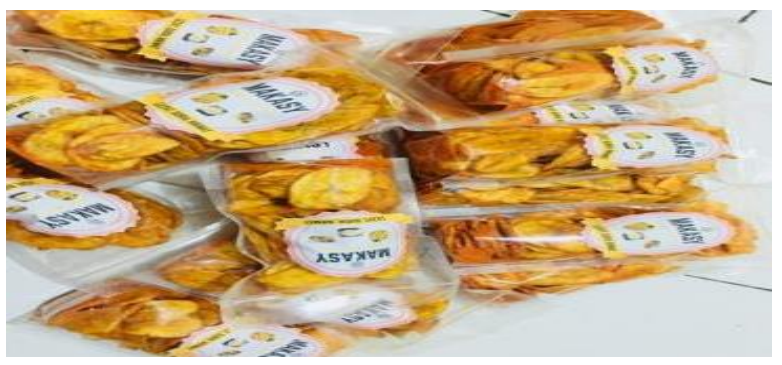

Gambar 2. Pengemasan Keripik Pisang

Pada gambar 2 menjelaskan bahwa tahap pengemasan keripik pisang.Pengemasan dilakukan bertujuan untuk meningkatkan daya simpan produk.Pengemasan menggunakan bahan plastik polipropilien dan diberi lebel agar menarik konsumen serta kepercayaan pada produk keripik pisang Makasy.

Untuk tempat sementara ini kami produksi di tempat tinggal saya sekarang yang beralamat di Jln. Sadewa $11 \mathrm{Km} .12$ masuk perumahan KPR bersubsidi Blok B11 dan menggunkan kendaraan pribadi sebagai tempat stok barang sehingga bila ada konsumen yang mau mebeli maka kami langsung antar kerpik tersebut ke konsunem tersebut. Promosi yang ami melakukan promosi dari mulut ke mulut yaitu mulai dari keluarga, teman, sahabat, serta dosendosen yang ada di UM-Sorong. Promosi melalui social media (Facebook, Whatsapp dan Instagram).

\section{SIMPULAN}

Pisang (,Musa Paradisiaca) merupakan salah satu komoditas buah unggulan Indonesia yang memiliki kontribusi besar terhadap produksi buah - buahan nasional lainnya. Tanaman 
pisang di Indonesia dapat tumbuh subur di dataran rendah maupun dataran tinggi serta pada iklim basah maupun iklim kering. Buah pisang dapat ditemui dimana saja setiap saat karena tidak tergantung pada musim, sehingga tidak perlu menunggu lama untuk dapat memproduksi dan mengkonsumsi.Pisang merupakan komoditas yang paling banyak dikonsumsi masyarakat indonesia, karena sekitar $45 \%$ konsumsi buah-buahan adalah pisang, pisang sering dimakan segar, dibikin kolak, dibakar dan dikukus atau dibuat tepung. Pisang dapat dimakan dalam berbagai cara, bisa dibuat kue, digoreng, dan direbus. Bukan hanya itu pisang juga dapat di olah menjadi sesuatu yang sangat unik, yaitu membuat pisang menjadi keripik.

Keripik pisang merupakan salah satu jenis cemilan ringan yang memiliki penggemar yang cukup banyak.Bahkan penggemar cemilan ringan ini mencakup semua kalangan baik anak - anak hingga orang dewasa.Oleh karena itu olahan keripik pisang merupakan salah satu peluang usaha bagi mahasiswa karena dari olahan pisang yang biasa dengan adanya kreativitas dan inovasi dari mahasiswa sehingga dapat menghasilkan keripik pisang dengan varian rasa baru sehingga menjadikan keripik pisang memiliki nilai jual lebih tinggi dengan modal yang tidak terlalu besar.

\section{DAFTAR PUSTAKA}

Iis Tristiana Iswan,(2013), Strageti Pengembangan Produktivitas dan Pemasaran Keripik Pisang "Banachip". (http://digilib.unhas.ac.id/uploaded_files/temporary/DigitalCollection/NmYwODRiM TVhYjI4YTVhMGNjNzJkN2FkMGFiNDIINTNiNTRiMWY5MA ==.pdf)

Hesti Budiwati,(2012), Implementasi Marketting Mix dan Pengaruhnya Terhadap Keputusan Pembelian Konsumen Pada Produk Unggulan Keripik Pisang Anggung di Kabupaten $\begin{array}{lllll}\text { Lumajang, Jurnal } & \text { Wiga } & \text { Vol.2 } & \text { No. } & 2\end{array}$ (https://www.neliti.com/publications/36622/implementasi-marketing-mix-danpengaruhnya-terhadap-keputusan-pembelian-konsumen)

Bayu,(2012), Strategi pengembangan Agroindustri keripik pisang di kecamatan Tawangmangu Kabupaten Karanganyar, Jurnal Agrista. (https://digilib.uns.ac.id/dokumen/detail/30700/Strategi-Pengembangan-AgroindustriKeripik-Pisang-Di-Kecamatan-Tawangmangu-Kabupaten-Karanganyar)

Irene Lisa Matantu,(2018), Pengembangan Strategi Pemasaran Keripik Pisang Pada Industri Raja Bawang di Kota Palu, Jurnal Agrotekbis 6(1). (http://jurnal.untad.ac.id/jurnal/index.php/Agrotekbis/article/view/11600)

Agustiana Vina,(2018), Pengaruh Marketting Mix Terhadap Keputusan Pembelian Produk Unggulan Keripik Pisang di Bandar Lampung, Sarjana Tesis Universitas Brawijaya. (http://repository.ub.ac.id/10854/) 